Jpn. J. Oral Biol., $37:$ 194-200, 1995.

\title{
ORIGINAL
}

\section{Lamellar bodies of mouse taste buds after fixation with tannic acid}

\author{
Masako Takeda, Yuko Suzuki, Nobuko Obara and Yasuko Nagai \\ Department of Anatomy, Health Sciences University of Hokkaido, School of Dentistry \\ Tobetsu, Ishikari, Hokkaido 061-02, Japan
}

[Received on December 19, 1994 ; Accepted on April 6, 1995]

Key words : taste bud/lamellar body/phospholipid/surfactant/tannic acid

\begin{abstract}
Circumvallate papillae of adult dd-mice were fixed in a mixture of tannic acid, glutaraldehyde, and paraformaldehyde, postosmicated, embedded in Epon, and observed under an electron microscope. An accumulation of globular electron-dense bodies ( $70 \sim 500 \mathrm{~nm}$ in diameter) was found in the apical cytoplasm of the three types of slender taste bud cells, and among the microvilli in the taste pores. High-resolution micrographs of these bodies revealed a lamellar structure with a period of $5 \mathrm{~nm}$, which is characteristic of phospholipids. It is likely that tannic acid in the fixative reacts with the choline base of phospholipids to form an insoluble complex of lamellar bodies. In vivo, the phospholipids may be diffusely distributed throughout the apical cytoplasm and released into the taste pores, and may thus act as a surfactant to promote the solubility of sapid materials, which facilitates their adsorption to the membranes of microvilli of taste bud cells.
\end{abstract}

\footnotetext{
抄録：成熟 dd-マウスの有郭乳頭をタンニン酸とグルタールアルデヒド，およびパラホルムアルデヒド混液で 前固定後, オスミウム酸で後固定し, エポンにより包理し, 透過電子顕微鏡で観察した。多数の球形の高電子密

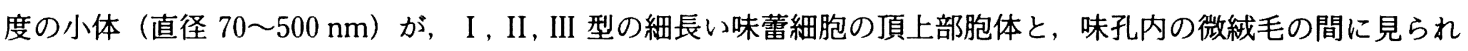
た。この小体を高倍率で観察すると， $5 \mathrm{~nm}$ の間隔を持つ同心円状の構造を呈した。これは, リン脂質を含むもの に特徵的に見られる像であり, 固定液中のタンニン酸がリン脂質の構成成分のコリン塩基と結合して, 不溶性物 質を作ったものと考えられる。すなわち, 味蕾細胞の中のリン脂質は, in vivo では, 頂上部胞体に拡散しており, それが味孔内に放出され, 味物質の溶解性を促進する界面活性剤として働くことにより, 味蕾細胞の微絨毛膜へ の味物質の吸着を容易にするものと推測される。
}

\section{Introduction}

The initial event in tasting is the adsorption of sapid materials to a receptor site on the microvillous membrane of the gustatory cells in the taste pores. As a consequence, the potential of the cells changes, which in turn evokes a nerve impulse in the gustatory afferent nerves ${ }^{1,2}$.

Taste bud cells in mammals have been classified into four types. Type-IV cells are localized in the basal areas of taste buds, and differentiate into elongated type- I ,-II, and-III cells, which extend from the basement membrane to the apical taste pores $^{3 \sim 7)}$. Type-I cells contain dense secretory granules (100 $\sim 200 \mathrm{~nm}$ in diameter) in their apical cytoplasm, which they release into the taste pores. The granules are thought to be composed mainly of glycoprotein ${ }^{6}$. However, the detailed composition of the substance in the taste pores remains unclear. The cytoplasm of type-II cells contains numerous vacuoles and smooth endoplasmic reticulum (sER). The function of these cells is unknown. Type-III (receptor) cells have afferent synaptic contacts with nerve terminals and a long, slender apical cytoplasmic process, and contain densecored vesicles $(80 \sim 100 \mathrm{~nm}$ in diameter) scattered 
throughout their cytoplasm ${ }^{3 \sim 5,8 \sim 10}$ ).

It has been reported that fixation with tannic acid before osmication preserves the ordered lamellar structure of saturated phospholipids, which are unable to react directly with $\mathrm{OsO}_{4}$ in the absence of pretreatment with tannic acid ${ }^{11,12}$. In this study, taste buds were fixed with a mixture of tannic acid, glutaraldehyde, and paraformaldehyde followed by osmication, and the distribution of lamellar bodies in the apical cytoplasm of taste bud cells and in the taste pores was investigated.

\section{Materials and Methods}

Adult dd-mice were housed in temperature-and humidity-controlled rooms. They received food and water ad libitum and were kept on a diurnal light schedule before use. Five mice $(7 \sim 15$ weeks) were intraperitoneally anesthetized with Nembutal, and then perfused through the left ventricle with a mixture of $0.5 \%$ tannic acid, $2 \%$ glutaraldehyde, and $4 \%$ paraformaldehyde in $0.1 \mathrm{M}$ phosphate buffer. Small blocks of the tongues containing circumvallate papillae were excised and immersed in the abovementioned fixative overnight at $4^{\circ} \mathrm{C}$. Some mice were treated with the above-mentioned fixative which lacked tannic acid. The tissues were postfixed in $1 \%$ $\mathrm{OsO}_{4}(0.1 \mathrm{M}$ phosphate buffer $)$ for $2 \mathrm{~h}$ at $4^{\circ} \mathrm{C}$. After embedding in Epon 812, thin sections were cut, stained with uranyl acetate and lead citrate, and observed with an electron microscope.

\section{Results}

An accumulation of globular electron-dense bodies was found in the apical cytoplasm of all three differentiated types (type- I ,-II, and-III) of taste bud cells, which extended from the basement membrane to the taste pore (Fig. 1). These bodies, ranging from 70 to $500 \mathrm{~nm}$ in diameter, were frequently fused together. The accumulation was localized in a belt-like zone below the level of tight junctions, surrounding the taste pores (Fig. 2). High-resolution micrographs of the bodies revealed an ordered lamellar structure with a period of $5 \mathrm{~nm}$, thus forming concentric circles, which is characteristic of phospholipids (Fig. 4). Most of the bodies laid freely in the cytoplasm (Fig. 5), and only a few appeared to be limited by a membrane (Fig. 6). Some bodies were occasionally observed in the perinuclear and basal area or in the intercellular space (Fig. 6). Lamellar bodies which were limited by a membrane were rarely found in taste buds treated with fixative that lacked tannic acid (Fig. 3).

In the taste pores, dense bodies with a lamellar structure were observed among the microvilli and occasionally on the cell membrane of the taste bud cells, suggesting that bodies were released to the taste pores through the cell membrane (Figs. 7, 8). Vesicles (40 $80 \mathrm{~nm}$ in diameter) and round bodies $(20 \sim 50$ $\mathrm{nm}$ ) were buried in the dense substance of the taste pores (Fig. 7), and they were also observed in specimens treated with fixative that lacked tannic acid.

Epithelial cells and their intercellular spaces lining the circumference of the taste pores showed many lamellar bodies (Figs. 1, 9), in contrast to epithelial cells that were situated far from the taste pores. The bodies were seldom found inside the grooves of circumvallate papillae. Some epithelial cells in the surface layer at the bottom of the grooves, where the excretory ducts of von Ebner glands (VEG) open, and some acinar and duct cells of von Ebner glands had a few lamellar bodies (Fig. 10).

\section{Discussion}

Tannic acid reacts primarily with the choline base of phosphatidylcholine and sphingomyelin in phospholipids to form a complex, which is stabilized by treatment with $\mathrm{OsO}_{4}$ to preserve the highly ordered structure during embedding procedures ${ }^{12)}$. Kalina and Pease $^{12)}$ revealed that "low molecular weight" (less than 1,000) tannic acid used with glutaraldehyde penetrated to reach the secretory bodies of type II pneumocytes.

The apical cytoplasm of all slender taste bud cells contained many lamellar bodies, and most were not limited by a membrane. These lamellar structures with a period of $5 \mathrm{~nm}$ are characteristic of a phospholipid-containing substance ${ }^{12}$. It is likely that tannic acid in the fixative reacts with the choline base of 


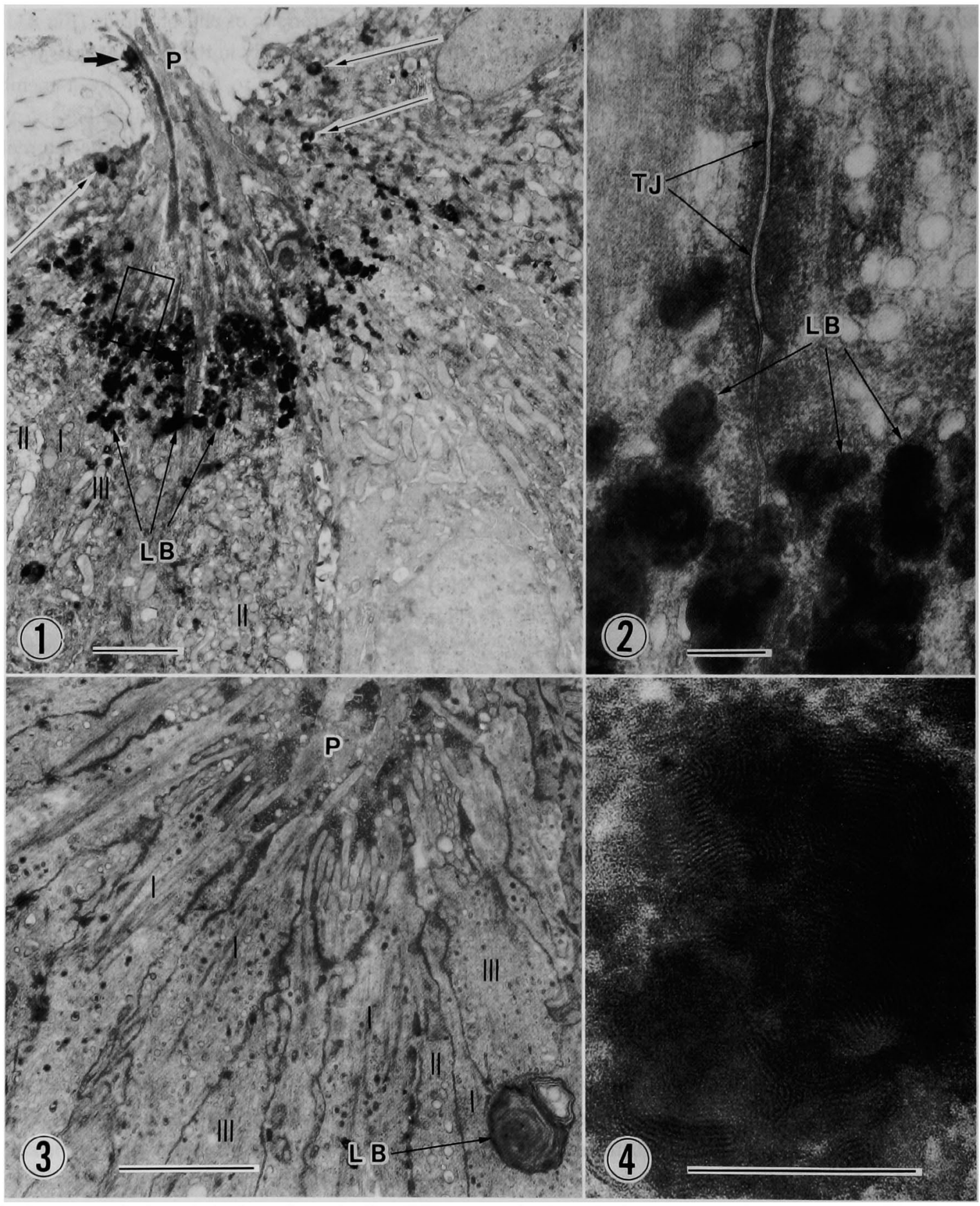

Fig. 1 An accumulation of electron-dense bodies (LB) is seen in the apical cytoplasm of all slender taste bud cells. The bodies are also seen in the taste pore (short arrow) and epithelial cells (long arrows) near the pore. $\mathrm{P}:$ taste pore, I : type-I cell, II : type-II cell, III : type-III cell. $\times 6,700$ Bar $: 2 \mu \mathrm{m}$

Fig. 2 High-resolution micrograph of the boxed area in Figure 1. The accumulation of lamellar bodies (LB) is localized below the level of a tight junction (TJ) in a belt-like form surrounding the taste pore. $\times 60,000 \mathrm{Bar}: 0.2 \mu \mathrm{m}$

Fig. 3 Taste bud treated with fixative lacking tannic acid. A lamellar body (LB) is seen in a type-I cell. I : type-I cell, II : type-II cell, III : type-III cell, P : taste pore. $\times 11,000$ Bar $: 2 \mu \mathrm{m}$

Fig. 4 High-resolution micrograph of electron-dense bodies of Figure 1. The bodies reveal a lamellar structure with a repeating period of $5 \mathrm{~nm} . \times 177,000$ Bar : $0.2 \mu \mathrm{m}$ 


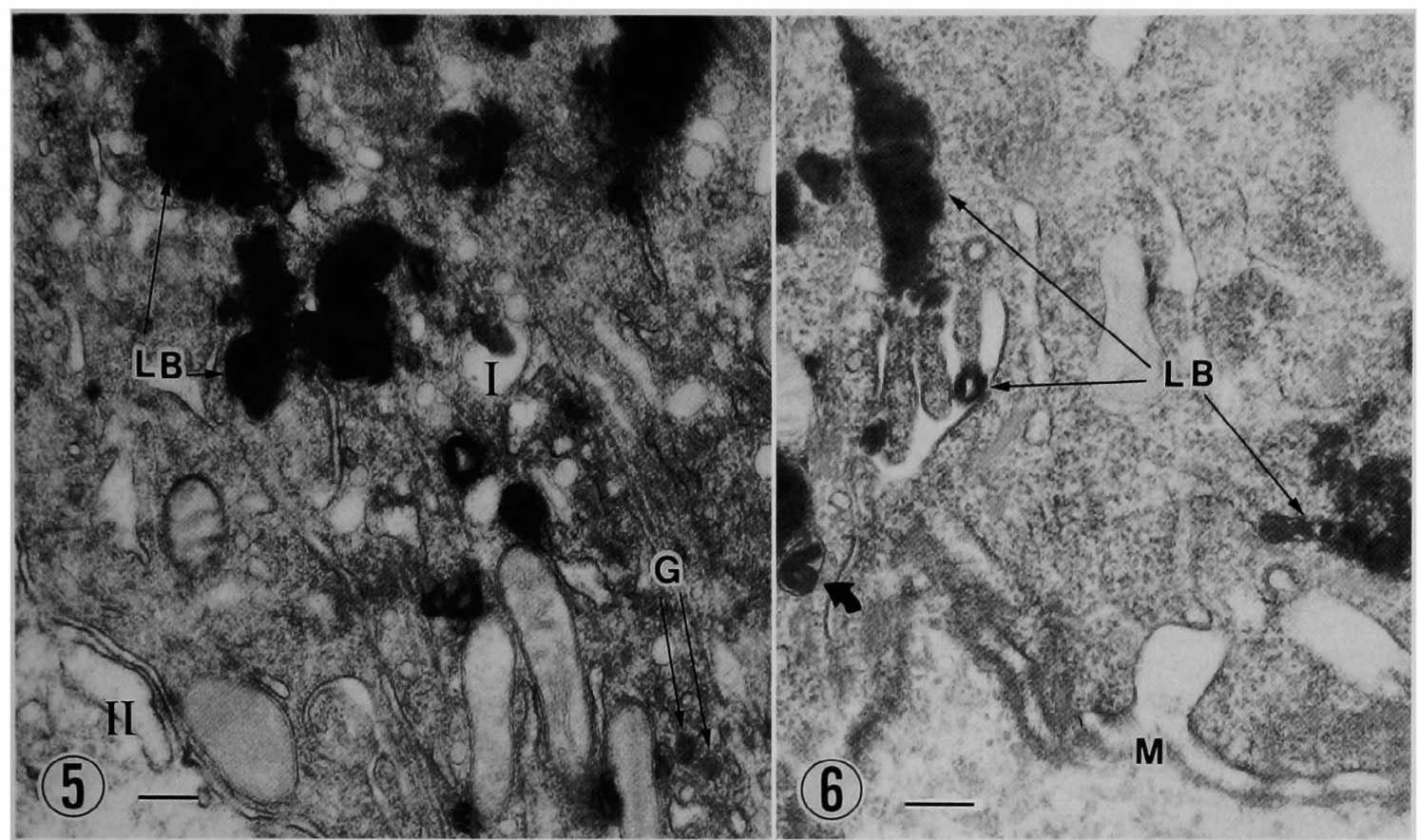

Fig. 5 Most of the lamellar bodies (LB) lay freely in the cytoplasm. G : dense granules of type-I cell, I : type-I cell, II : type-II cell. $\times 28,000$ Bar $: 0.2 \mu \mathrm{m}$

Fig. 6 Lamellar bodies (LB) are observed in the basal part of a taste bud cell. A body (short arrow) is limited by a membrane. $\mathrm{M}$ : basement membrane. $\times 34,000$ Bar : $0.2 \mu \mathrm{m}$

phospholipids in the taste buds to form an insoluble complex with a lamellar structure. In vivo, phospholipids may be diffusely distributed throughout the taste bud cells, and are released into the taste pores through the cell membrane by diacrine secretion without modification of the membrane, by analogy with steroid hormone-secreting cells, e. g. adrenocortical cells ${ }^{13,14)}$.

This explanation may be also supported by the fact that a few lamellar bodies are situated on the cell membranes of taste bud cells which border the taste pores. On the other hand, some lamellar bodies, which are limited by a membrane and situated in the perinuclear or basal cytoplasm of taste bud cells, may correspond to lysosomes.

Epithelial cells containing lamellar bodies, which are located near the taste pores or in the surface layer at the bottom of the grooves, may release a phospholipid-containing substance into the taste pores or grooves of the papillae. Similarly, acinar cells with a few lamellar bodies in the von Ebner glands may release such a substance.
Type-II pneumocytes of the lung possess secretory bodies with a lamellar structure that contain a high proportion of saturated phospholipids in a lipid-protein complex. These are released into the lumen of alveoli to act as a surfactant to reduce the surface tension at the air-liquid interface ${ }^{15-18}$. In lung tissue treated with tannic acid before osmication, highly ordered arrays of lamellar bodies have been observed in type-II pneumocytes, and not all are limited by a membrane. Similar bodies have been seen in Clara, ciliated, and goblet cells of the trachea and bronchi. In addition, lamellar structures are spread over the sur. face of the alveolar lumen. Presumably, the secretory products of all of these cells act as surfactants ${ }^{19211}$.

The environment of the taste pores is maintained by secretions from taste bud cells and VEG cells, the ducts of which open into the grooves of the papillae. The pore substance secreted from type-I taste bud cells supposedly contains a glycoprotein that is stained by ruthenium red ${ }^{6}$. Phospholipids may associate with this glycoprotein to form a complex in the taste pores. VEG protein, which has been character- 


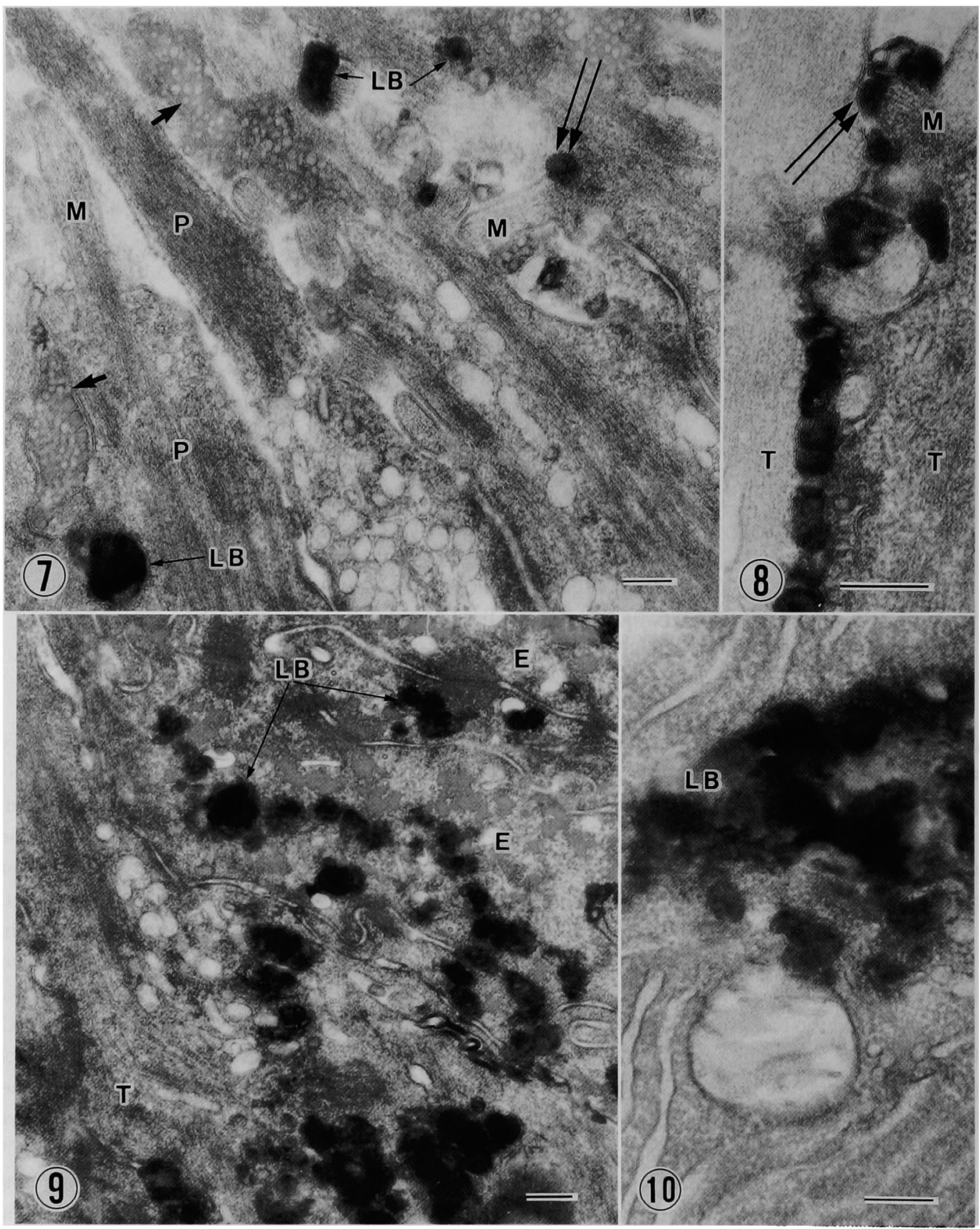

Figs. 7, 8 In the taste pore, lamellar bodies (LB) are seen among the microvilli (M) and processes (P) of taste bud cells. Some lamellar bodies (double long arrows) are situated on the cell membrane. Dense substances with clear round bodies (short arrows) are seen. $\mathrm{T}$ : apical cytoplasm of taste bud cells. Bar: $0.2 \mu \mathrm{m}$. Fig. 7. $\times 40,000$, Fig. $8 . \times 67,000$

Fig. 9 Epithelial cells (E) near the taste pore contain many lamellar bodies (LB). T : apical cytoplasm of a taste bud cell. $\times 34,000$ Bar : $0.2 \mu \mathrm{m}$

Fig. 10 An acinar cell of the von Ebner gland contains some lamellar bodies (LB). $\times 54,000$ Bar : $0.2 \mu \mathrm{m}$ 
ized as a member of a lipophilic ligand carrier protein family, has been detected immunohistochemically in VEG acini and in the grooves of circumvallate and foliate papillae. It presumably controls the access of lipophilic sapid molecules, such as bitter substances, to the gustatory receptors ${ }^{22,23)}$.

Bile, the exocrine secretion of hepatocytes, contains phospholipids (lecithin) and acts as a surfactant that emulsifies fat so that lipase is more effective in the small intestine ${ }^{24}$. Our findings suggest that phospholipids in the taste pores act as a surfactant to promote the solubility of sapid materials, which facilitates their adsorption to the membranes of microvilli of taste receptor cells. VEG protein, which has been characterized as a member of a lipophilic ligand carrier protein family, may contribute to this surfactant action.

\section{References}

1) Beidler, L. M. : Biophysics and chemistry of taste. In: Handbook of perception. Vol. VI. Tasting and smelling (Carterette, E. C. and Friedman, M. P.), pp. 21 49, Academic Press, New York, San Francisco, London, 1978.

2) Kruger, L. and Mantyh, P. W. : Gustatory and related chemosensory systems. In : Handbook of chemical neuroanatomy. Vol. 7. Integrated systems of the CNS, Part II, Central visual, auditory, somatosensory, gustatory (Bjorklund, A., Hokfelt, T. and Swanson, L. W.), pp. 323 411, Elsevier, Amsterdam, New York, Oxford, 1989.

3) Murray, R. G., Murray, A. and Fujimoto, S. : Fine structure of gustatory cells in rabbit taste buds. J. Ultrastruct. Res. $27: 444 \sim 461,1969$.

4) Fujimoto, S. and Murray, R. G. : Fine structure of degeneration and regeneration in denervated rabbit vallate taste buds. Anat. Rec. 168:393 414, 1970.

5) Murray, R. G. : The ultrastructure of taste buds. In: The ultrastructure of sensory organs (Friedmann, I.), pp. 1 81, North-Holland, Amsterdam, London and American Elsevier, New York, 1973.

6) Takeda, M. and Hoshino, T. : Fine structure of taste buds in the rat. Arch. Histol. Jpn. $37: 395$ $\sim 413,1975$.

7) Yoshie, S., Wakasugi, C., Teraki, Y. and Fujita, $\mathrm{T}$. : Fine structure of the taste bud in the guinea pigs. I. Cell characterization and innervation patterns. Arch. Histol. Cytol. 53 : 103 119, 1990.

8) Takeda, M. and Kitao, K. : Effect of monoamines on the taste buds in the mouse. Cell Tissue Res. $210: 71 \sim 78,1980$.

9) Takeda, M., Suzuki, Y. and Shishido, Y.: Effects of colchicine on the ultrastructure of mouse taste buds. Cell Tissue Res. 242: 409 416, 1985.

10) Takeda, M., Suzuki, Y., Obara, N. and Nagai, Y. : Neural cell adhesion molecule of taste buds. J. Electron Microsc. 41 : 375 380, 1992.

11) Stratton, C. J. : Multilamellar body formation in mammalian lung: An ultrastructural study utilizing three lipid-retention procedures. J. Ultrastr. Res. $50: 321 \sim 332,1975$.

12) Kalina, M. and Pease, D. C. : The preservation of ultrastructure in saturated phosphatidyl cholines by tannic acid in model systems and type II pneumocytes. J. Cell Biol. 74: 726 741, 1977.

13) Kurosumi, K. : Electron microscopic analysis of the secretion mechanism. Int. Rev. Cytol. $11: 1 \sim$ $124,1961$.

14) Fujita, H. and Fujita, T. : Epithelial tissue. In : Textbook of histology, Part 1, 3rd edn., pp. 97 121, Igaku-Shoin Ltd., Tokyo, 1988.

15) Askin, F. B. and Kuhn, C. : The cellular origin of pulmonary surfactant. Lab. Invest. $25: 260 \sim 268$, 1971.

16) Kikkawa, Y., Yamada, K., Smith, F., Packard, B. and Suzuki, K.: The type-II epithelial cells of the lung, II Chemical composition and phospholipid synthesis. Lab. Invest. 32: 295 302, 1975.

17) Kikkawa, Y. and Smith, F. : Cellular and biochemical aspects of pulmonary surfactant in health and disease. Lab. Invest. 49:122 139, 1983.

18) Walker, S. R., Williams, M. C. and Benson, B. : Immunocytochemical localization of the major surfactant apoproteins in type-II cells, Clara cells, and alveolar macrophages of rat lung. J. Histochem. Cytochem. 34:1137 1148, 1986.

19) Ueda, S., Kawamura, K., Ishii, N., Matsumoto, S., Hayashi, K., Okayasu, M., Saito, M. and Sakurai, I. : Ultrastructural studies on surface lining layer (SLL) of the lungs : Part III, Comparative study by light and electron microscopy with a use of a new fixation and fluorescence staining method. J. Jap. Med. Soc. Biol. Interface $15: 67 \sim 78,1984$. 
20) Ueda, S., Saito, J., Kawamura, K., Ishii, N., Matsumoto, S., Hayashi, K., Saito, M., Kinukawa, N. and Sakurai, I. : Ultrastructural studies of the lung surfactant. (6) Cells of respiratory tract related to secretion of surfactant. J. Clin. Electron Microsc. $21: 771 \sim 772,1988$.

21) Ueda, S. : Ultrastructural studies of the lung surfactant and its production cells. In: Lung surfactant (Yoshida, S.), pp. 27 47, Shinkoukoueki Inc., Tokyo, 1990.

22) Schmale, H., Holtgreve-grez, H. and Christiansen, H. : Possible role for salivary gland protein in taste reception indicated by homology to lipophilic-ligand carrier proteins. Nature $343: 366$ 〜369, 1990.

23) Kock, K., Blaker, M. and Schmale, H. : Postnatal development of von Ebner's glands: Accumulation of a protein of the lipocalin superfamily in taste papillae of rat tongue. Cell Tissue Res. 267 : 313 320, 1992.

24) Cormack, D. H. : Pancreas, liver, and gallbladder. In : Ham's histology. pp. 518 540, J. B. Lippincott Company, Philadelphia, 1987. 